\title{
Effects of stocking density and immersion time on the performance of oysters in intertidal off-bottom culture
}

\author{
Jacob J. Capelle ${ }^{1,2}$ D $\cdot$ Eva Hartog ${ }^{1} \cdot$ Jorik Creemers $^{1} \cdot$ Jouke Heringa $^{1}$ • \\ Pauline Kamermans ${ }^{2}$
}

Received: 8 March 2019 / Accepted: 18 August 2019 / Published online: 5 September 2019

(C) The Author(s) 2019

\begin{abstract}
Intertidal culture in meshed bags on trestles is worldwide the most established culture method for oysters. Culturists can affect oyster performance by adjusting stocking density and immersion time, and it can be expected that these factors are not independent. The combined effect of stocking density and immersion time on survival, growth and condition of oysters was investigated on a culture site, where oysters are usually stocked at $8 \mathrm{~kg} \mathrm{bag}^{-1}$. Half-grown oysters were stocked in three biomass densities: 4,8 and $12 \mathrm{~kg} \mathrm{bag}^{-1}$, nested within three immersion times (87\%, $76 \%$ and $73 \%$ of tidal cycle). Chlorophyll-a concentration peaked in summer $\left(\sim 3-10 \mu \mathrm{g} \mathrm{l}^{-1}\right)$ and was low in autumn $\left(\sim 1 \mu \mathrm{g} \mathrm{l}^{-1}\right)$, and high chlorophyll-a levels coincided with oyster spawning period. Survival was not affected by density or immersion time. Shell growth per oyster and biomass production per bag were density dependent- higher at 4 than at $12 \mathrm{~kg} \mathrm{bag}^{-1}$ — but neither were different from $8 \mathrm{~kg} \mathrm{bag}^{-1}$. Growth rates were negativity related with immersion over the spawning period but showed a (non-significant) positive trend over other periods. At harvest, condition per oyster decreased with stocking density and increased with immersion. There was no interaction between density and immersion. Treatments had a more pronounced effect on meat content than on biomass production. Hence, oysters might be kept at higher stocking densities to increase biomass production during most of the growth cycle but restocked in lower densities, with longer immersion times prior to harvest to maximize meat content at harvest.
\end{abstract}

Keywords Magallana gigas (Crassostrea gigas) - Split-plot design · Density dependent · Trestle culture Shellfish culture

\section{Introduction}

Extensive shellfish aquaculture is largely dependent on the environment for seed and feed. Optimizing culture practices or system design for culture is based on anticipating to this

Jacob J. Capelle

jacob.capelle@wur.nl

Extended author information available on the last page of the article 
environment. Shellfish farmers anticipate food availability by trying to optimize shellfish density, mostly based on experience, by adjusting stocking density and thinning-out practices. Shellfish density affects growth and survival when individuals compete for food or for space (Marshall and Dunham 2013; Honkoop and Bayne 2002; Fréchette and Bacher 1998).

Oysters are the foremost cultured species in volume in global aquaculture production, and much of the oyster culture takes place in intertidal areas (FAO 2018). Oysters in intertidal areas are subjected to different immersion times that at some point affect growth and survival (Vincent et al. 1994). At the same time, it might very well present an opportunity for the oyster growers to manipulate growth and survival.

In the Netherlands, Pacific oyster (Magallana gigas) cultivation is mainly carried out on subtidal bottom plots (Drinkwaard 1999). However, oyster production is under pressure, it suffers from large mortalities, mainly due to the oyster herpes virus (Engelsma et al. 2010), but also other threats such as the oyster drill Ocenebra inornata (a predatory snail) (Faasse and Ligthart 2009). This development calls for a number of measures, including more efficient and productive culture techniques. Recently, a consortium of Dutch oyster growers has started experimenting with culturing oysters in the intertidal in meshed bags on trestles. Worldwide the most established culture method for M. gigas (Buestel et al. 2009; Forrest et al. 2009), but a novel culture method for the Netherlands.

The culture cycle currently starts with oyster seed collected with seed collectors (coupelles) that are employed at the culture site, or with oyster spat from a hatchery. About $5 \mathrm{~kg}$ of oyster seeds (ca. 5000 seeds) are stocked in $0.5 \mathrm{~m} \times 1 \mathrm{~m}$ bags with a 6-mm mesh until they are about $25-40 \mathrm{~mm}$ and restocked in lower biomass densities $(2.2 \mathrm{~kg})$ in bags with $12-\mathrm{mm}$ mesh. After 8-10 months, oysters are restocked in bags with 16-mm mesh in a biomass density of $8 \mathrm{~kg}$ bag $^{-1}$ for grow-out until harvest that occurs usually at the end of the year (Nov-Dec). The outgrow phase also takes place with half-grown oysters that are handpicked from wild oyster beds. During the outgrow phase, oyster bags are turned manually every $2-4$ weeks. Some farmers treat fouling, especially seaweed fouling by spraying $9.5 \%$ acetic acid during low tide.

At new culture sites and with a new culture technique, oyster growers are facing questions on optimization of production. It can be expected that factors that affect performance are not independent but act cumulative. Here, we present the results of a large-scale experiment on combined effects of density and immersion on the performance of cultured oysters. At the scale of culture units, it was investigated how the combined effect of stocking density and immersion time affected survival, growth and condition of oysters stocked in meshed bags on trestles in the low intertidal area in relation to on-site food quantity. It is expected that survival, growth and condition decrease with density and that the magnitude of this effect increases at lower immersion times and in periods with lower food levels.

\section{Material and methods}

\section{Area}

From 17 April 2014 to 9 December 2014, a field experiment was carried out at an oyster culture site $\left(2500 \mathrm{~m}^{2}\right)$ located on an intertidal mudflat in the Oosterschelde estuary, the Netherlands $\left(51^{\circ} 34^{\prime} 53.86^{\prime \prime} \mathrm{N} ; 3^{\circ} 53^{\prime} 15.74^{\prime \prime} \mathrm{E}\right)$. At start of the experiment, the entire site consisted of 1470 meshed bags, with ca. 200 oysters per bag (approx. 118 oysters $\mathrm{m}^{-2}$ over the entire oyster culture site), on trestles arranged in 16 rows (Fig. 1). The oyster tables were 
set out parallel to the water's edge, and the incoming tide followed the rows from the row with the experimental locations $\mathrm{A}: \mathrm{C}$, then to the row with locations $\mathrm{D}: \mathrm{F}$, and then to row with locations G:I (Fig. 1/b). Current directions over the culture plot were measured using ultrasonic flow meters (Acoustic Doppler Current Profilers, Nortek AS) at the edge of the culture plot (site A, Fig. 1) prior to the experiment (on 7-9 April 2014), when the trestles were present, but the oyster bags not placed yet. A calibrated logger-type chlorophyll and turbidity meter (ACLW2-USB, JFE Advantech) became available in July and was installed at the same height as the oyster bags at site A (Fig. 1) and measured at a 10-min interval from 14 July to 9 December 2014.
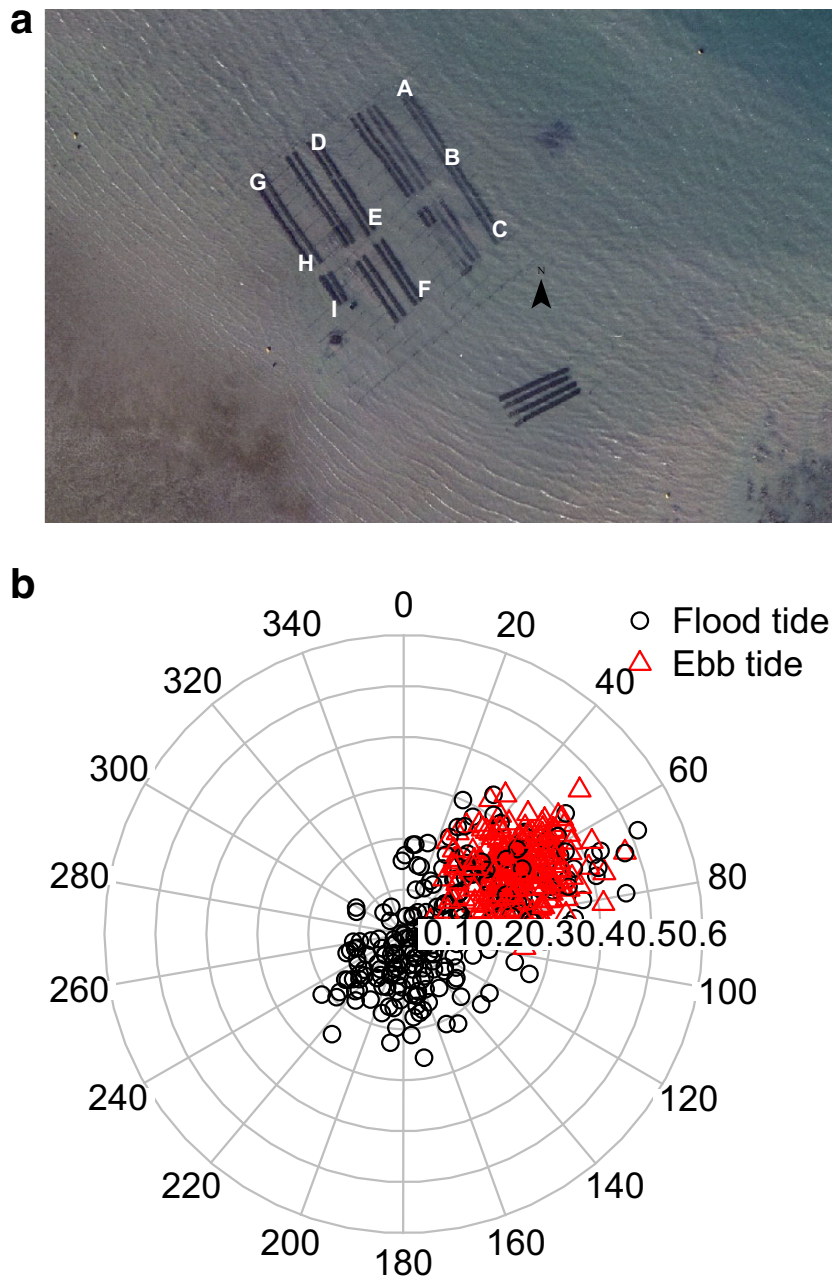

Fig. 1 a Arial view of the experimental site $\left(\sim 2000 \mathrm{~m}^{2}\right)$ with 16 rows of meshed bags (1470 bags in total) on trestles, taken in March 2014 (C 2013, Esri Nederland and Grontmij Nederland); experimental locations are indicated by letters (A-I), and the arrow indicates North. b Radar plot with current velocities $\left(\mathrm{m} \mathrm{s}^{-1}\right)$ on the horizontal axis and with current direction in degrees relative to the North, which is set at $0^{\circ}$. Velocity measurements were carried out over 3 days (7-9 April 2014) with a 10-min interval $50 \mathrm{~cm}$ above the sediment at location $\mathrm{A}$ in $\mathrm{A}$ 


\section{Experimental setup}

Oysters used for the experiment were redistributed from bags that were already lying on the culture plot. These were handpicked oysters from the intertidal Oosterschelde stocked during the autumn (September-November) of 2013. The oyster grower generally stocks half-grown oysters (about $40-50 \mathrm{~g}$ ) in a biomass of $8 \mathrm{~kg} \mathrm{bag}^{-1}$. We selected oysters within a size class of $71.4 \pm 10.4 \mathrm{~mm}$, the estimated average size of half-grown oysters from the commercial stock. The average oyster wet weight at the start of the experiment was $49.98 \mathrm{~g} \pm 15.52 \mathrm{~g}$. To deal with size variation, individual oysters were followed. To achieve this, 30 oysters were randomly selected from each bag and individually marked before the experiment started. Marking was done by engraving a Roman numeral, from 1 to 30 , behind the umbo in the ventral-dorsal direction on the shell (Fig. 2). To keep marked oysters together, they were placed in a small 'inner' bag $(70 \times 30 \mathrm{~cm}$, mesh $12 \mathrm{~cm})$, which was placed in the larger 'outer' bags that were used to culture the oysters. Size of the inner bags was large enough to prevent competition for space within the inner bag. Oyster bags were treated by the culture company like all other oyster bags on site, including turning the bags and fouling removal.

Oyster performance (growth rate, mortality rate, and condition index) was tested at different immersion times and at different initial densities according to a split-plot design. Due to practical constraints in the field, it was not possible to spread the experiment on statistically independent line of metal trestles. The split plot design manages this problem through blocking (here by location). Therefore, oyster bags $(100 \times 50 \mathrm{~cm}$, mesh size $12 \mathrm{~mm})$ chosen for the experiment were relayed at nine experimental locations, indicated by A:I in Fig. 1. To test the effect of stocking density, we restocked the bags in three different densities based on mass:

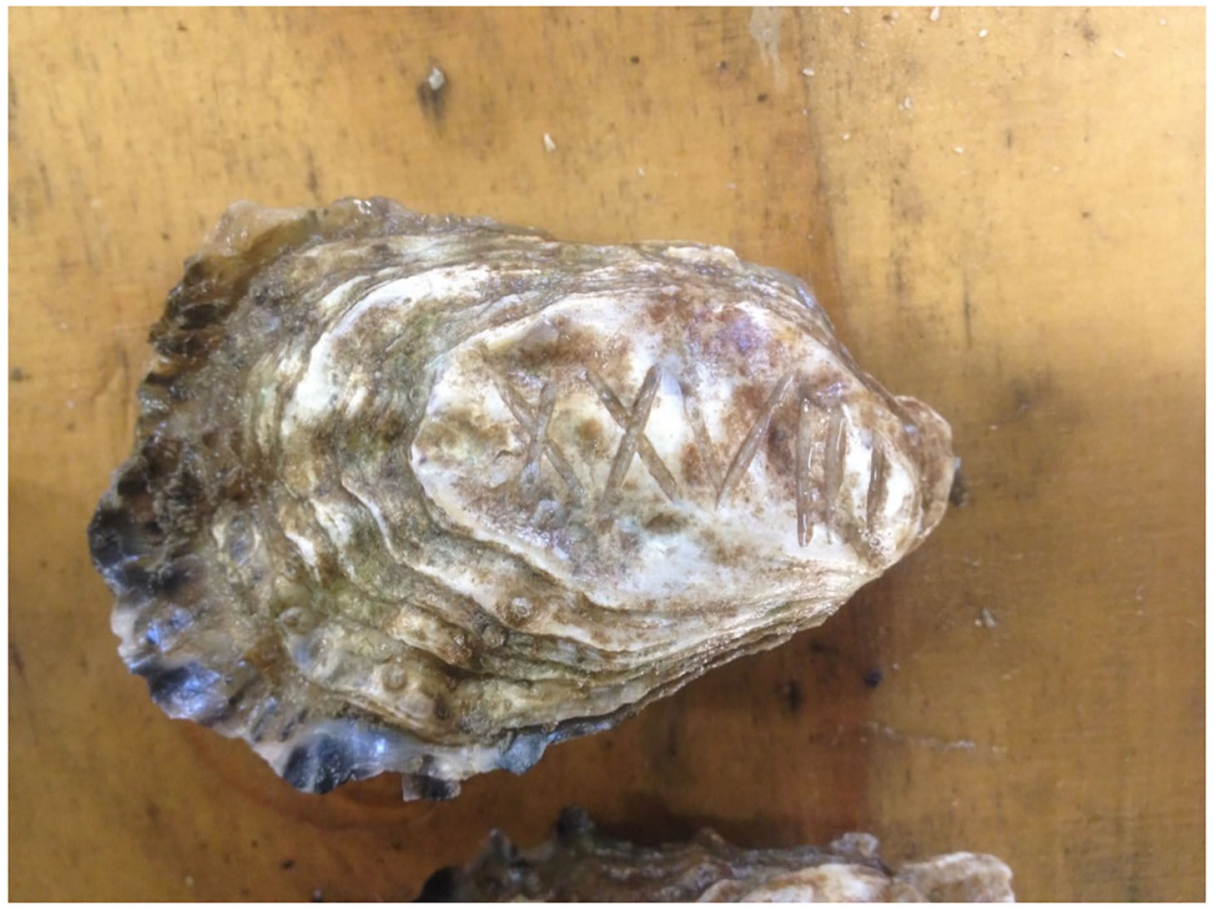

Fig. 2 Engraved oyster shell (ca. $70 \mathrm{~mm}$ ) reading number 28 in Roman numerals in the ventral-dorsal direction 
$4 \mathrm{~kg} \mathrm{bag}^{-1}, 8 \mathrm{~kg} \mathrm{bag}^{-1}$ and $12 \mathrm{~kg} \mathrm{bag}^{-1}$. Bags containing three different biomass densities were placed in triplicate and randomly at the nine locations (A:I in Fig. 1) on the trestles at each site. In total, 81 oyster bags were distributed over nine locations with totals of 27 bags with $4 \mathrm{~kg}$ bag $^{-1}, 27$ bags with $8 \mathrm{~kg} \mathrm{bag}^{-1}$ and 27 bags with $12 \mathrm{~kg} \mathrm{bag}^{-1}$. This setup also provided three different immersion times. The longest immersion time ( $87 \%$ of tidal cycle) was covered by sites A, B, and C (Fig. 1), the intermediate immersion time ( $76 \%$ of tidal cycle) was covered by sites D, E, and F (Fig. 1), and the shortest immersion time (73\% of tidal cycle) was covered by sites G, H, and I (Fig. 1). All treatments are summarized in Fig. 3.

\section{Sampling}

Oysters were placed in the field at 25th of April and were collected four times between the start and the end of the experimental period: 26-28 May, 7-8 Jul, 25-26 Aug and 22-24 Sep. Oysters were taken to the laboratory, a 30-min drive from the field site. At each sampling moment, maximum ventral-dorsal shell length was recorded for each individual marked oyster, and the individual wet weight was obtained. After measurement, the oysters were kept in a basin with running saline groundwater (with $28 \mathrm{~g} \mathrm{l}^{-1}$ about the same salinity as the Oosterschelde estuary) and relayed to the site the next day.

Final measurement was achieved in the period from 1 December to 9 December 2014. On five days, a randomized number of bags were taken from the field. After measuring the length and wet weight, a subset of oysters was sacrificed for further analysis. The subset consisted of 17 random oysters from each bag. The oysters were opened, the meat was collected and weighed, and the 'wet' shells were weighed. The dry weight of the oyster meat was obtained by drying it at $80{ }^{\circ} \mathrm{C}$ in a prepASH (prepASH® 340 series, http://prepash.com) until the change in weight of each sample was less than $0.1 \%$ per $0.5 \mathrm{~h}$. The ash weight was obtained by heating at $540{ }^{\circ} \mathrm{C}$ in a prepASH until the change in weight of each sample was less than $0.1 \%$ per $0.5 \mathrm{~h}$. The ash-free dry weight (AFDW) was calculated as the net difference between the dry weight and the ash weight.

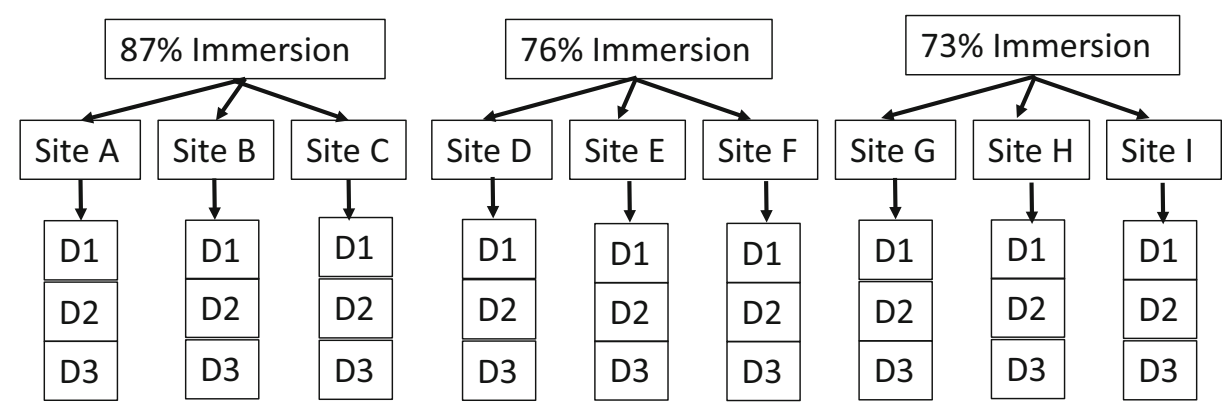

Fig. 3 Scheme of experimental setup, $\mathrm{D}=$ density and is through blocking (Site) hierarchically linked to Immersion time. D1 = $4 \mathrm{~kg} / \mathrm{bag}, \mathrm{D} 2=8 \mathrm{~kg} / \mathrm{bag}, \mathrm{D} 3=12 \mathrm{~kg} / \mathrm{bag}$; each density was triplicated and randomly placed within a site, resulting in $n=81$ experimental units (bags) divided over 27 treatments, with 3 experimental units per treatment. Oysters from all bags at all sites were measured until the end of the experiment apart from Site F, where all bags were accidentally harvested before the experiment was finished, hence $n=72$ at harvest 


\section{Data analysis}

There are two studied factors in this design: immersion time as main factor, density as subfactor, with location as blocks. Measurements of individual oysters are utilized, but these measurements are nested to a bag (practical constraints) and each bag is nested to the interaction immersion time $\times$ stocking density and bags are triplicated (Fig. 3). Variability between the locations in the split-plot design was used in a nested ANOVA to test the effects of the main factor (immersion time); the variability between the triplicated bags was used to test the effects of the sub-factor (stocking density) and its interaction with immersion time; and at the lowest level of the nested design, the variability between measurements on each oyster is the error term of the ANOVA and was only used to test the between bag variability.

The oyster farmer harvested oysters from the culture plot shortly before the final measurement period (Dec 2014). At location F, all the experimental oyster bags were accidentally harvested, and these oysters were lost in the process. This introduced two main sources of unbalancing i.e. (1) absence of results for the F location and (2) oyster mortalities. As stated by Sokal and Rohlf (1981) p. 293, nested ANOVAs with unequal sample sizes generate complications about (1) computations that become much more tedious and (2) absence of exact tests of significance. Therefore, homogeneity of variance assumption that can result from the missing F location was carefully checked in all models, and in the case of overall mortality, we considered it still possible to use a balanced data set with only one value (total mortality rate) per bag.

Standardized residuals of the ANOVAs were checked for normality using a histogram and were plotted against fitted values and against each explanatory variable to validate the model. The residuals followed a normal distribution closely, and no violation of homogeneity was indicated. When significant overall effects were found, pairwise comparisons were made by means of a Tukey HSD test from the agricolae package for R (de Mendiburu 2017). Two possible sources of pseudo-replication were identified in the analysis: (1) repeated measurements on the same oyster and (2) spatial autocorrelation. Problems with repeated measures (for growth data) were minimized due to the large sample size per treatment (in total 2430 engraved oysters were stocked), similar origin and size of the oysters and randomisation at stocking. Spatial autocorrelation was investigated by plotting the residuals of the model in a variogram. Residuals in the variogram showed no increase or decrease; spatial autocorrelation could not be detected.

Growth rates between sampling points and over the experimental period were calculated for shell length as $\left(L_{\text {end }}-L_{\text {start }}\right) / t$, with $L$ as maximum individual oyster's shell length in $\mathrm{mm}$ and $t$ time in days and for oyster wet weight as $\left(W_{\text {end }}-W_{\text {start }}\right) / t$, with $W$ as individual wet weight $(\mathrm{g})$. Mortality rates during the experimental period were calculated per bag as $\ln \left(n_{\text {start }}\right)-\ln \left(n_{\text {end }}\right) / t$, with $n$ as number of oysters per inner bag $\left(n_{\text {start }}=30\right)$ and $t$ time in days. The market value of oysters for the industry is strongly connected to quality or meat content. We used condition index (CI) of the oysters as a measure of meat content. CI at the end of the experiment was calculated as [dry tissue weight $(\mathrm{g}) /$ shell cavity volume] $\times 100$, with wet oyster weight $(\mathrm{g})$ minus shell weight (g) as a proxy for the shell cavity volume (Abbe and Albright 2003). Relative biomass production ratio (BPR) is relevant for culture practices and is defined by growth and mortality. It is expressed as $\left(B_{\text {end }} / B_{\text {start }}\right)$, with $B$ as oyster biomass $(\mathrm{kg})$ per bag. Differences between treatments were tested according to the same procedure used for growth rate. 


\section{Results}

Current velocities at ca. $50 \mathrm{~cm}$ above the sediment (the same height as the oyster bags) (location A, Fig. 1) were in a range of $0-20 \mathrm{~cm} \mathrm{~s}^{-1}$ at flood tide and $0-40 \mathrm{~cm} \mathrm{~s}^{-1}$ at ebb tide (Fig. 1b). The mean chlorophyll-a concentration over the entire experimental period from April-December 2014 was $4.02 \mu \mathrm{g} \mathrm{l}^{-1}$. Average chlorophyll-a concentrations over the periods when oyster samples were taken (indicated by I, II and III in Fig. 4) were $3.4 \mu \mathrm{g} \mathrm{l^{-1 }}$ over period I, $7.2 \mu \mathrm{g}^{-1}$ over period II and $1.8 \mu \mathrm{g}^{-1}$ over period III. There was no overall significant relation between growth rates $\left(\mathrm{g} \mathrm{day}^{-1}\right)$ and chlorophyll-a content (Fig. 5a-c for the different densities and Fig. 5d-f for the different immersion times). However, in period I, growth rates decreased with density $(F(12,2)=12,14, p=0.001)$; oysters placed in low-density showed significantly higher growth rates than at the highest density, but there was no difference with the reference biomass of $8 \mathrm{~kg} \mathrm{bag}^{-1}$. There was no effect found for the different immersion times. In period II, chlorophyll-a levels showed maximum values, but this period is also the period when oysters spawn (Troost 2009) and, as a result, oyster weight dropped. Growth rates decreased with stocking density and were significantly higher at the lowest density compared to the other densities $(F(12,2)=4.92, p=0.03)$. Growth rates were lower at the longest immersion time, and a negative interaction between density and immersion time $(F(12,4)=$ $8.46, p=0.002$ ) was found. In period III, growth rates also decreased with stocking density and were significantly lower at the high-density treatment than at the reference and low-density treatment $(F(12,2)=33.14, p<0.001)$.

Over the entire experimental period (April-December), growth rates in shell length $\left(\mathrm{mm} \mathrm{day}{ }^{-1}\right)$ decreased with initial stocking density (Table 1$)$. Here, $4 \mathrm{~kg}$ per bag showed higher growth rates than $12 \mathrm{~kg}$ per bag, but no indication was found that the starting densities of $4 \mathrm{~kg}$ per bag and $12 \mathrm{~kg}$ per bag differed from the reference stocking density of $8 \mathrm{~kg}$ per bag (Fig. 6).

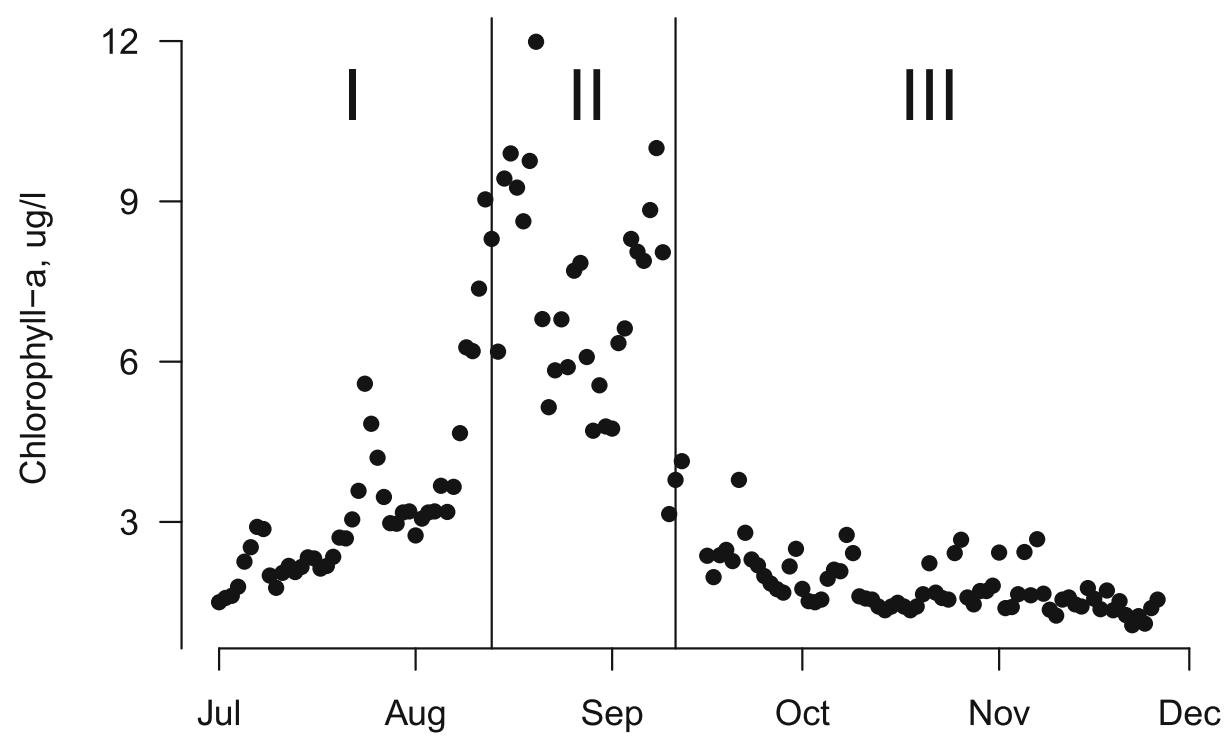

Fig. 4 Daily averaged (measured at a 10 min interval) chlorophyll-a concentration $(\mu \mathrm{g} / 1)$ at the experimental site (location A, Fig. 1), from July to December 2014; I, II and III indicate periods over which oyster growth was measured 

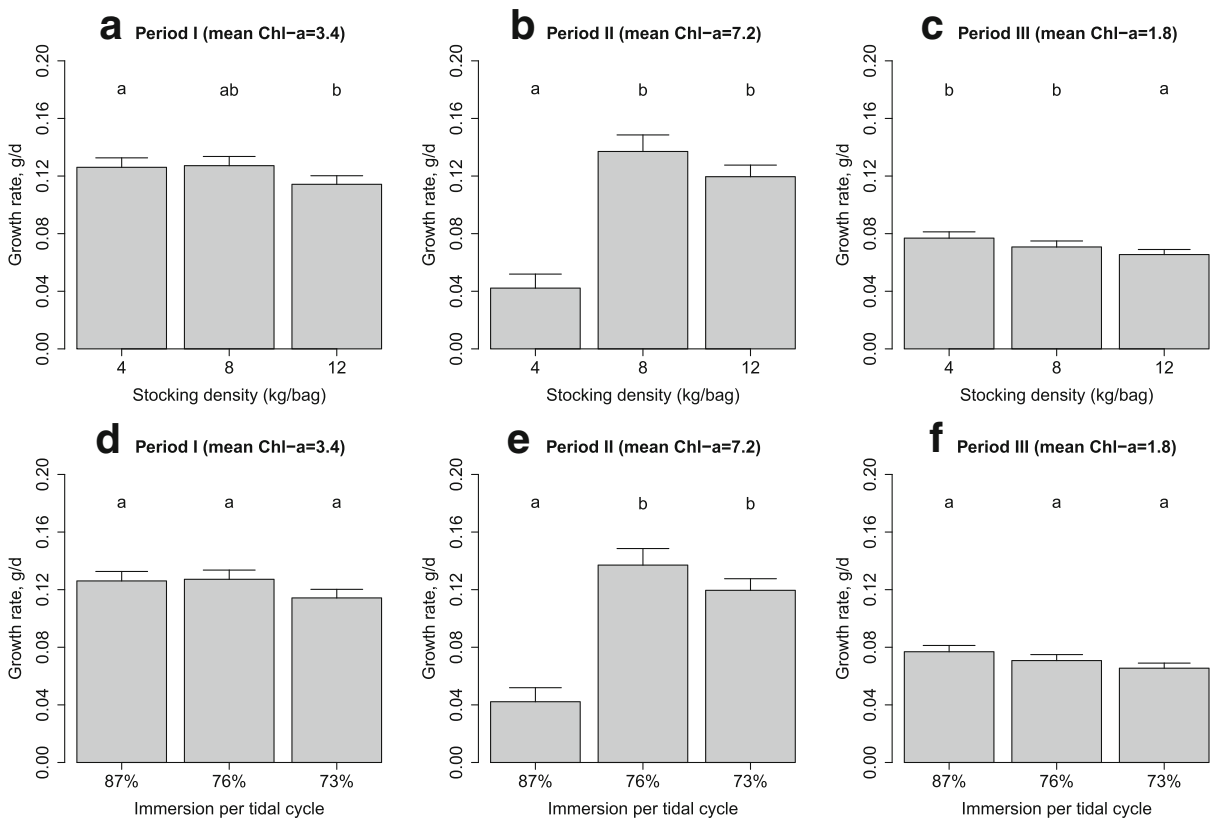

Fig. 5 Growth rates (+ se) in gram wet weight per day over three periods (I: 7-8 Jul to 25-26 Aug, II: 26-27 Aug to 22-24 Sep, and III: 23-25 Sep to 1-9 Dec) with the average Chlorophyll-a levels per period. Plot a-c shows the effect of different stocking densities. Plot $\mathbf{d}-\mathbf{f}$ shows the effect of different immersion times

Average oyster mortality per bag was $22 \%$ (mortality rate 0.00051 day $^{-1}$ ) over the entire experimental period (April-December), 7\% per bag mortality occurred in the first month, increased to $9 \%$ in the second month and decreased steadily towards $0 \%$ at the end of the year. No relation was found between oyster mortality rate per bag and the effect of immersion time or stocking density (Fig. 7).

The per bag biomass production ratio (BPR) is the result of growth and mortality from the start to the end of the experiment (Fig. 8). When this ratio is one, growth fully compensates for mortality, when this ratio is above one; the net growth is higher than is the net mortality. In all density treatments, a net biomass production was observed. No evidence could be found that the BPR of the reference stocking biomass of $8 \mathrm{~kg}$ per bag differed from the BPR of 4 and

Table 1 Split-plot ANOVA for growth rate in millimetre per day, with immersion time as the main plot factor and density as subplot factor

\begin{tabular}{llllll}
\hline Growth rate (mm/day) & SS & $d f$ & MS & $F$ & $P$ \\
\hline Main plot & & & & & 0.063 \\
$\quad$ Immersion & 0.0012 & 2 & 0.0006 & 0.94 \\
$\quad$ Main plot error & 0.048 & 5 & & & \\
Subplot & & & & 0.0096 & 0.003 \\
$\quad$ Density & 0.073 & 2 & 0.036 & 0.09 \\
$\quad$ Density $\times$ immersion & 0.035 & 4 & 0.0032 & & \\
$\quad$ Subplot error & 0.032 & 10 & & & \\
\hline
\end{tabular}




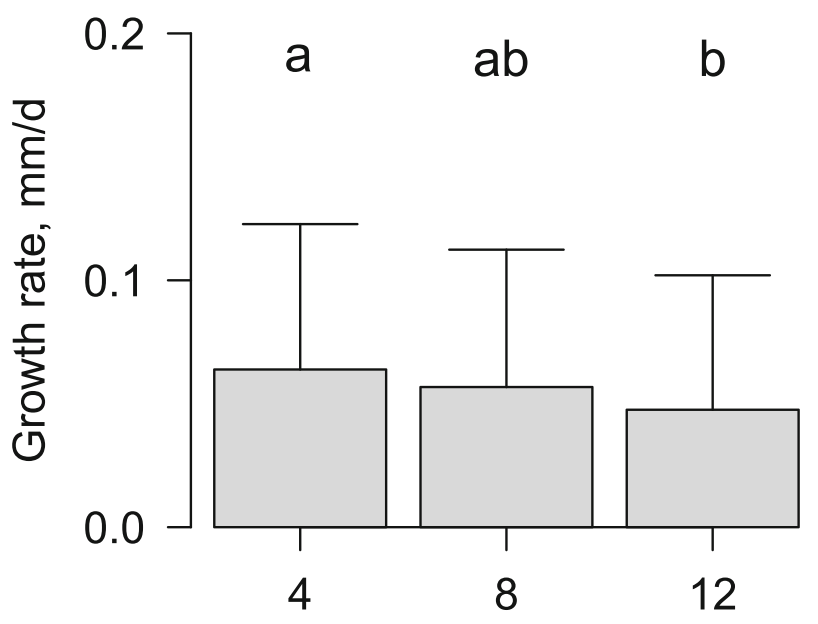

\section{Stocking biomass, $\mathrm{kg} / \mathrm{bag}$}

Fig. 6 Effect of initial stocking biomass on the average growth rate per oyster $(+\mathrm{sd})$ in millimetres per day calculated over the experimental period (April-December 2014); $\mathrm{a}$ is different from $\mathrm{b}(\alpha=0.05)$

$12 \mathrm{~kg}$ per bag. However, at an initial stocking density of $4 \mathrm{~kg}$ per bag, a significantly higher BPR was found than at an initial stocking density of $12 \mathrm{~kg}$ per bag (Fig. 8 and Table 2).

Condition index at the end of the experiment was negatively related to initial stocking density and was positively related to immersion time (Table 3 and Fig. 9). In this relationship,
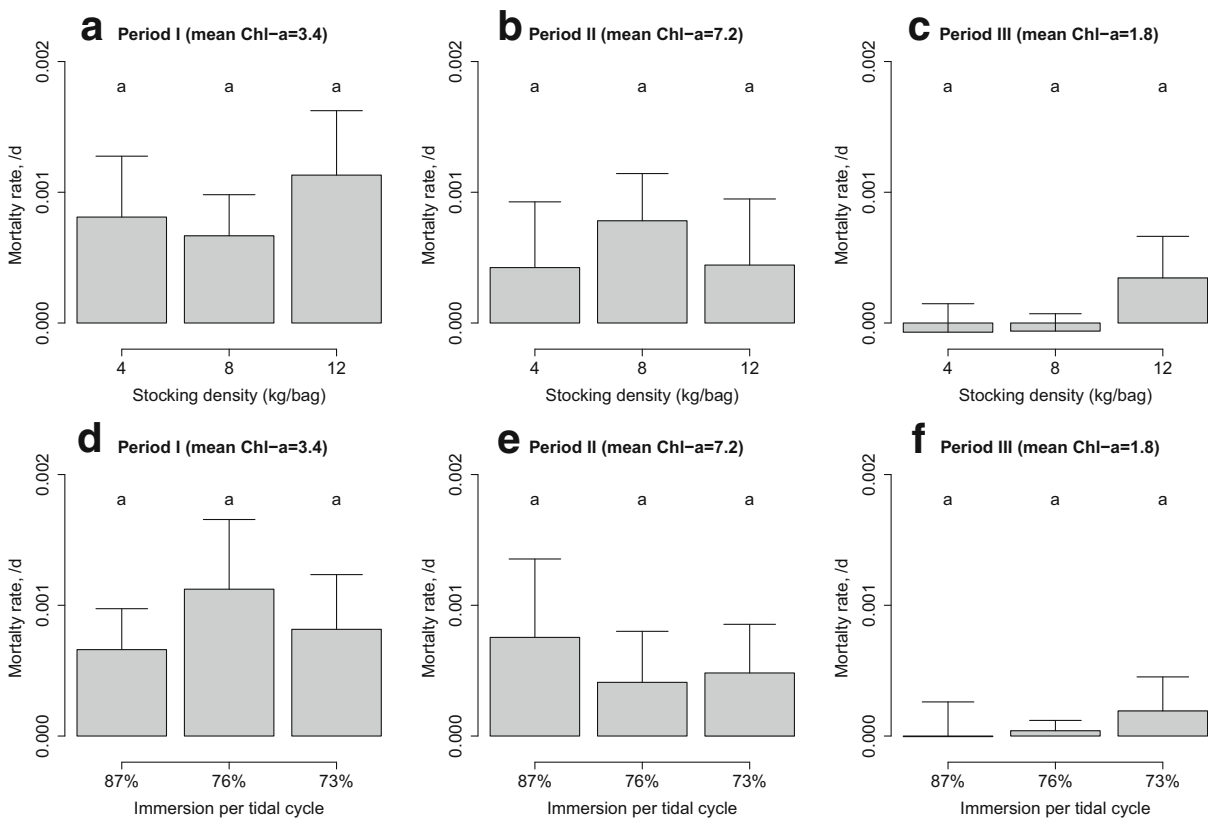

Fig. 7 Mortality rates $\left(\mathrm{d}^{-1}, \pm \mathrm{se}\right)$ in gram wet weight per day over three periods (I: 7-8 Jul to 25-26 Aug, II: 2627 Aug to 22-24 Sep, and III: 23-25 Sep to 1-9 Dec) with the average Chlorophyll-a levels per period. Plot a-c shows the effect of different stocking densities. Plot $\mathbf{d}-\mathbf{f}$ shows the effect of different immersion times 


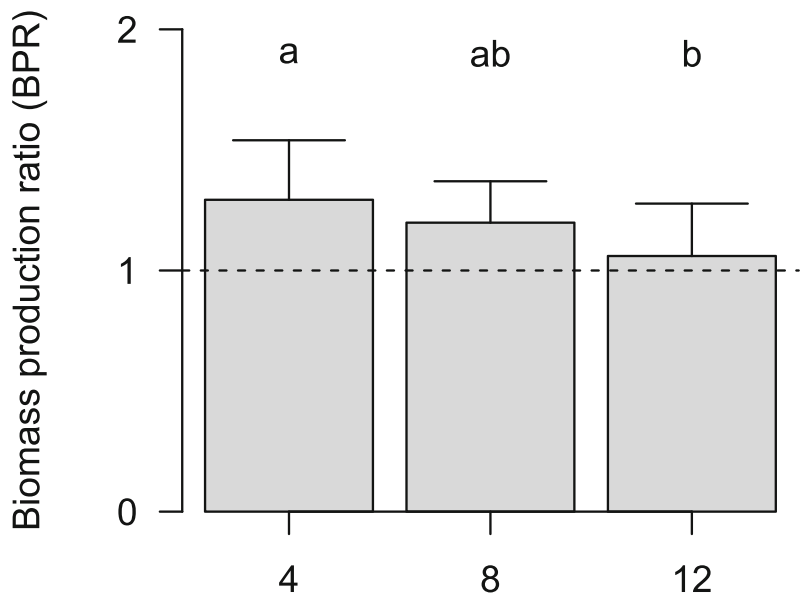

Stocking biomass, $\mathrm{kg} / \mathrm{bag}$

Fig. 8 Effect of initial stocking biomass on the biomass production ratio (RBP) per bag $(+\mathrm{sd})$ calculated over the experimental period (April-December 2014); $\mathrm{a}$ is different from $\mathrm{b}(\alpha=0.05)$

no interaction was found between stocking density and immersion time. Condition index was significantly higher at an initial stocking density of $4 \mathrm{~kg}$ per bag than at an initial stocking density of $8 \mathrm{~kg}$ per bag, which was significantly higher than at an initial stocking density of $12 \mathrm{~kg}$ per bag (Fig. 9a). Furthermore, condition index was significantly higher at a low immersion time (87\%) than at immersion times of 76 and $73 \%$ (Fig. 9b).

\section{Discussion}

We found density-dependent effects and effects of immersion period on the performance of the oysters, but no evidence was found for an interaction effect between immersion time and stocking density.

\section{Effect of stocking density}

Growth rates reflect food availability over the period it is measured (Pouvreau et al. 2006). However, not all food is transferred to shell or tissue growth, a proportion of the food is

Table 2 Split-plot ANOVA for biomass production ratio (BPR), with immersion time as the main plot factor and density as subplot factor

\begin{tabular}{llllll}
\hline BPR & SS & $d f$ & MS & $F$ & $P$ \\
\hline Main plot & & & & & \\
$\quad$ Immersion & 0.06 & 2 & 0.031 & 0.25 & 0.79 \\
$\quad$ Main plot error & 0.62 & 5 & 0.12 & 5.60 & 0.02 \\
Subplot & & & 0.32 & 0.86 & 0.52 \\
$\quad$ Density & 0.64 & 2 & 0.05 & \\
$\quad$ Density $\times$ immersion & 0.20 & 4 & 0.06 & & \\
$\quad$ Subplot error & 0.58 & 10 & & & \\
\hline
\end{tabular}


Table 3 Split-plot ANOVA for condition index of the oysters at the end of the experiment (December) with immersion time as the main plot factor and density as subplot factor

\begin{tabular}{llllll}
\hline Condition index & SS & $d f$ & MS & $F$ & $P$ \\
\hline Main plot & & & & & \\
$\quad$ Immersion & 156.91 & 2 & 78.45 & 15.34 & 0.007 \\
$\quad$ Main plot error & 25.58 & 5 & 5.12 & & \\
Subplot & & & & 74.11 & $<0.001$ \\
$\quad$ Density & 226.4 & 2 & 113.20 & 1.64 & 0.24 \\
$\quad$ Density $\times$ immersion & 29.50 & 4 & 7.38 & & \\
$\quad$ Subplot error & 45.07 & 10 & 4.51 & & \\
\hline
\end{tabular}

allocated for reproduction and maintenance (Bernard et al. 2011). Oysters store glycogen in vesicular cells outside the growing season (November-March), which is diverted to gametogenesis in spring and summer (Berthelin et al. 2000). Spawning in the Oosterschelde area generally takes place in the period August-September (Troost 2009), when food levels are high (period II: Fig. 4); spawning-associated weight loss resulted in low growth rates in this period, and there was no difference in growth rates between the high density treatment and reference density of $8 \mathrm{~kg}$ per bag (Fig. 5b). In the period after spawning (and preceding harvest), the oysters recover from spawning, but in this time of year, food levels have dropped (period III: Fig. 5c).

Results point out that growth of the oysters was negatively affected by density. This pattern was consistent over all measured periods, i.e. at all food levels. Furthermore, condition index was more sensitive to detect such patterns than changes in shell length or wet weight. However, differences in condition index are probably dependent on timing of the samples taken. In shellfish, growth rate integrates variation of food availability over the period that it is measured, while condition index is a measure that reflects feeding conditions in a short period prior to measurement (Filgueira et al. 2013; Pouvreau et al. 2006; Capelle et al. 2016). Because condition index is a proxy for meat content and sampling is destructive, it was only measured in the period when meat content matters for oyster growers, which is in the harvest period

a Immersion

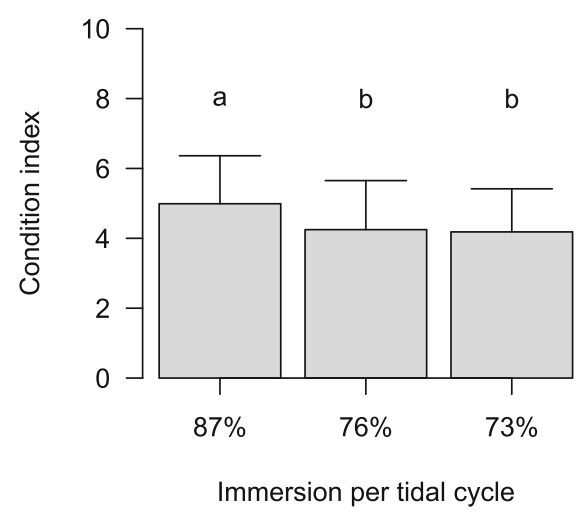

b Stocking biomass

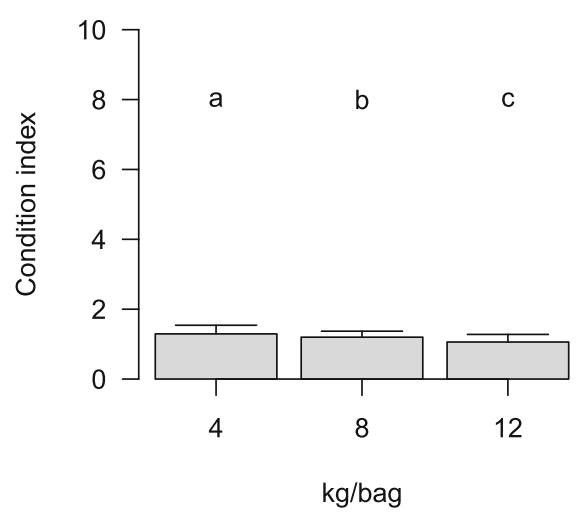

Fig. 9 Effect of immersion time (a) and stocking biomass (b) on the condition index per oyster (+ se) at the end of the experiment (December 2014); $\mathrm{a}$ is different from $\mathrm{b}(\alpha=0.05)$ 
(December). Practically, meat content can be increased by decreasing stocking biomass prior to harvest.

Oysters were handled intensively at the start of the experiment when engraving their shells. This handling did not result in substantial oyster mortality, and mortality showed no peak at the first sampling moment. Furthermore, oyster mortality was not related to stocking density. Mortality at our study site was in line with other studies in Europe (Soletchnik et al. 2002; Syvret et al. 2008).

Biomass production is determined by the growth and survival during the period between stocking and harvest. Therefore, the biomass yield in extensive bivalve mollusc culture is determined by the extent to which growth can offset mortality (Petraitis 1995; Dare and Edwards 1976). The relative biomass production ratio (RBP) at the reference stocking density of $8 \mathrm{~kg}$ per bag was not different when densities were either decreased by $50 \%$ or increased by $50 \%$. Differences in RBP are hereby similar to differences in growth rates, because mortality was not density dependent.

In the current set-up, the total experiment did not change the effective density of the site, since an equal number of bags had 50\% reduction and 50\% increase in stocking density. It is expected that when the effective density of the site increases, growth will be more reduced. Several tools are developed to estimate this production capacity of a (potential) culture site based on the environment and farm configuration (e.g. in Hawkins et al. 2013, and in Ferreira et al. 2009). However, when a shellfish population is maintained below the exploitation carrying capacity at farm or site scale, density-dependent processes (e.g. due to local food or space limitation) still might occur within a farm at the culture unit scale. Examples are found for oysters in cages (Manley et al. 2009; Robertson et al. 1987), mussels on longlines (Rosland et al. 2011), mussels on bottom plots (Capelle et al. 2014) or scallops in nets (Zhang et al. 2006). At the current set-up, we found that the half-grown oysters were not easily overstocked and biomass production per area can be substantially increased by increasing stocking biomass per bag.

\section{Effect of immersion time}

We found that growth rates were lowest at highest immersion time in summer; this is when food levels were highest and when spawning takes place, while during the other periods, there was no trend. Meat content (condition index) at harvest was higher at lower densities and when oysters were longer immersed. Survival was not affected by density or immersion period.

Contrary to what was expected, oyster growth rate and survival rate were not higher when longer immersed. It was expected, i.e. based on Spencer et al. (1978), that longer immersion times provide longer access to food and support higher growth rates in shellfish. However, this relationship does not appear to be straightforward for oysters under field conditions, due to various confounding factors that might affect growth. For example, in Wales, where Pacific oysters were exposed to air ( $100-70 \%$ immersion), no effect on survival was found, but growth increased with immersion (Spencer et al. 1978). However, in another study in Wales, King et al. (2006) found no difference in growth between cultured M. gigas that were exposed to air for $4 \mathrm{~h}(\sim 33 \%$ immersion $)$ and oysters that were exposed to air for $1 \mathrm{~h}(\sim 83 \%$ immersion) per tidal cycle, according to the authors, probably, because of food competition due to heavier fouling and heavier Polydora sp. infestation when longer submerged.

Sampling of natural oyster beds in the German Wadden Sea, Diederich (2006) showed that growth of $M$. gigas was not affected by the tidal level (nor by substrate or barnacle fouling). 
For $C$. virginica, no effect of immersion on growth was found when immersion period was above than 75\% (Roegner and Mann 1995). An improved (or higher than expected) growth when oysters are exposed to air for some time, compared to oysters that are submerged all the time, can occur when a periodic growth of oysters is higher than a continuous growth. This faster periodic growth can be caused by a stronger selection mechanism for the survival of fast growing individuals in the intertidal zone, or because of higher energy conservation and supplementation (Crosby et al. 1991; Gillmor 1982). Oysters also have an advantage to settle at higher shore levels, because there is a reduced predation pressure (Bartol et al. 1999). The development of natural $M$. gigas reefs in the Oosterschelde, where our study was also situated, is limited up to an immersion time of $45 \%$, and here, oysters showed the best performance at an immersion time of around $80 \%$ (Walles 2015). With an immersion of $73-87 \%$, our treatments were situated below and above this optimal immersion period.

A plausible reason why immersion had an effect on condition index but not on shell growth over the experimental period is due to spawning activities. It appears that oysters at lowest density and highest immersion time displayed the lowest growth rates (see Fig. 5e and also note the interaction between density and immersion time for that period). This is likely a result of the spawning activity. Delaporte et al. (2006) found that when oysters were kept at higher food levels during gonad development, they allocated the majority of their energy to gonads. Hence, oysters under more optimal conditions (low density and high immersion time - that resulted in the highest oyster condition at the end of the experiment) could have had a higher reproductive output and lost more weight to spawning. This suggests that a longer immersion period favours growth, but when in summer, food levels are high, most of the extra energy is allocated to gonadal development.

Condition at the end of the experiment was higher at an immersion time of $87 \%$ than it was for the two more similar immersion times of $76 \%$ and $73 \%$. This effect is likely caused by feeding time and not by food depletion, because the effects are clearly more related to the immersion periods at the site than to position on the plot relative to other oysters (e.g. middle vs edge). Soft tissue growth rates, i.e. changes in condition, can show different patterns in shellfish than growth in shell length. For example, in the ribbed mussel and in the blue mussel, soft tissue growth is accelerated after spawning, while shell growth decreases (Hilbish 1986; Borrero and Hilbish 1988). In the study of Honkoop and Bayne (2002) on density effects in Pacific oysters and Sydney rock oysters, shell growth and somatic growth were uncoupled and their results were very similar to our study: an overall density-dependent effect in condition, but a lesser effect on shell length.

\section{Implications for culture}

Optimal stocking densities has been defined in terms of biomass production as the minimum stocking densities that will produce the maximum biomass production (Fréchette et al. 1996). The optimal stocking density has also been defined more economically as the maximum return per culture unit, with oyster bags as culture units for trestle culture. Hence, the question is if the farmer wants to growth as much biomass (tonnes) of oysters as possible, or if the farmer wants to harvest oysters with as much meat content as possible? We found that this does not need to be mutually exclusive, because treatments had a different effect on meat content than on biomass production. Oysters might be kept at higher stocking densities to increase biomass production during most of the growth cycle, but restocked in lower densities, with longer immersion times 
prior to harvest to maximize meat content during harvest. An excellent follow-up study would evaluate cost-benefit of differing densities and immersion times at site scale.

Acknowledgements We thank the oyster companies Bonton, Prins \& Dingemanse and Roem van Yerseke for their cooperation in this project. From the HZ University of Applied Science, Ben van Heumen, Victor Devillers, Daniel Schissler, Ingrid Wong and Tony van der Hiele assisted with the field and lab work. From Wageningen Marine Research, Johan Jol, Emiel Brummelhuis, Ad van Gool, Carola van Zweeden and Jack Perdon assisted with the field and lab work. We thank two anonymous reviewers for their positive critical comments on earlier versions of this paper.

Funding information This work was part of the RAAK-PRO 'Zilte Productie' project and was funded by SIA.

\section{Compliance with ethical standards}

Conflict of interest The authors declare that they have no conflict of interest.

Ethical statement This article does not contain any studies with animals performed by any of the authors.

Open Access This article is distributed under the terms of the Creative Commons Attribution 4.0 International License (http://creativecommons.org/licenses/by/4.0/), which permits unrestricted use, distribution, and reproduction in any medium, provided you give appropriate credit to the original author(s) and the source, provide a link to the Creative Commons license, and indicate if changes were made.

\section{References}

Abbe GR, Albright BW (2003) An improvement to the determination of meat condition index for the eastern oyster, Crassostrea virginica (Gmelin 1791). J Shellfish Res 22(3):747-752

Bartol IK, Mann R, Luckenbach M (1999) Growth and mortality of oysters (Crassostrea virginica) on constructed intertidal reefs: effects of tidal height and substrate level. J Exp Mar Biol Ecol 237(2):157-184

Bernard I, de Kermoysan G, Pouvreau S (2011) Effect of phytoplankton and temperature on the reproduction of the Pacific oyster Crassostrea gigas:Investigation through DEB theory. J Sea Res 66:349-360

Berthelin C, Kellner K, Mathieu M (2000) Storage metabolism in the Pacific oyster (Crassostrea gigas) in relation to summer mortalities and reproductive cycle (west coast of France). Comp Biochem Physiol B: Biochem Mol Biol 125(3):359-369

Borrero FJ, Hilbish TJ (1988) Temporal variation in shell and soft tissue growth of the mussel Geukensia demissa. Mar Ecol Prog Ser 9-15

Buestel D, Ropert M, Prou J, Goulletquer P (2009) History, status, and future of oyster culture in France. J Shellfish Res 28:813-820

Capelle JJ, Wijsman JWM, Schellekens T, van Stralen MR, Herman PMJ, Smaal AC (2014) Spatial organisation and biomass development after relaying of mussel seed. J Sea Res 85:395-403

Capelle JJ, Wijsman JWM, van Stralen MR, Herman PMJ, Smaal AC (2016) Effect of seeding density on biomass production in mussel bottom culture. J Sea Res 110:8-15

Crosby M, Roberts C, Kenny P (1991) Effects of immersion time and tidal position on in situ growth rates of naturally settled eastern oysters, Crassostrea virginica (Gmelin, 1791). J Shellfish Res 10(1):95-103

Dare PJ, Edwards DB (1976) Experiments on the survival, growth and yield of relaid seed mussels (Mytilus edulis L.) in the Menai Straits, North Wales. J Cons Int Explor Mer 37:16-28

Delaporte M, Soudant P, Lambert C, Moal J, Pouvreau S, Samain J-F (2006) Impact of food availability on energy storage and defense related hemocyteparameters of the Pacific oyster Crassostrea gigas during an experimental reproductive cycle. Aquaculture 254:571-582

de Mendiburu F (2017) Agricolae: statistical procedures for agricultural research. R package version 1.2-7

Diederich S (2006) High survival and growth rates of introduced Pacific oysters may cause restrictions on habitat use by native mussels in the Wadden Sea. J Exp Mar Biol Ecol 328(2):211-227 
Drinkwaard AC (1999) Introductions and developments of oysters in the North Sea area: a review. Helgol Wiss Meeresunters 52:301-308

Engelsma M, Roozenburg I, Voorbergen-Laarman M, Haenen O (2010) Eerste detectie van oesterherpesvirus OsHv-1 in Nederland. Aquacultuur 25(6):36-39

Faasse M, Ligthart M (2009) American (Urosalpinx cinerea) and Japanese oyster drill (Ocinebrellus inornatus) (Gastropoda: Muricidae) flourish near shellfish culture plots in the Netherlands. Aquat Invasions 4(2):321326

FAO (2018) Fisheries \& aquaculture, global statistical collection; http://www.fao.org/fishery/statistics/en

Ferreira J, Sequeira A, Hawkins A, Newton A, Nickell T, Pastres R, Forte J, Bodoy A, Bricker S (2009) Analysis of coastal and offshore aquaculture: application of the FARM model to multiple systems and shellfish species. Aquaculture 289(1):32-41

Filgueira R, Comeau LA, Landry T, Grant J, Guyondet T, Mallet A (2013) Bivalve condition index as an indicator of aquaculture intensity: a meta-analysis. Ecol Indic 25:215-229

Forrest BM, Keeley NB, Hopkins GA, Webb SC, Clement DM (2009) Bivalve aquaculture in estuaries: review and synthesis of oyster cultivation effects. Aquaculture 298:1-2): 1-15

Fréchette M, Bacher C (1998) A modelling study of optimal stocking density of mussel populations kept in experimental tanks. J Exp Mar Biol Ecol 219:241-255

Fréchette M, Bergeron P, Gagnon P (1996) On the use of self-thinning relationships in stocking experiments. Aquaculture 145:91-112

Gillmor RB (1982) Assessment of intertidal growth and capacity adaptations in suspension-feeding bivalves. Mar Biol 68(3):277-286

Hawkins AJS, Pascoe PL, Parry H, Brinsley M, Black KD, McGonigle C, Moore H, C.R N, O'Boyle N, O'Carroll, O'Loan BO, Service M, Smaal AC, Zhang XL, Zhu MY (2013) SHELLSIM: a generic model of growth and environmental effects validated across contrasting habitats in bivalve shellfish. J Shellfish Res 32:237-253

Hilbish TJ (1986) Growth trajectories of shell and soft tissue in bivalves: Seasonal variation in Mytilus edulis L. J Exp Mar Biol Ecol 96(2):103-113

Honkoop PJC, Bayne BL (2002) Stocking density and growth of the Pacific oyster (Crassostrea gigas) and the Sydney rock oyster (Saccostrea glomerata) in port Stephens, Australia. Aquaculture 213(1):171-186

King JW, Malham SK, Skov MW, Cotter E, Latchford JW, Culloty SC, Beaumont AR (2006) Growth of Crassostrea gigas spat and juveniles under differing environmental conditions at two sites in Wales. Aquat Living Resour 19:289-297

Manley JA, Power ARL, Walker RL (2009) Comparison of techniques for off-bottom culture of the eastern oyster, Crassostrea virginica (Gmelin, 1791), in Georgia. . In: Occasional Papers of the University of Georgia Marine Extension Service, pp. 16

Marshall RD, Dunham A (2013) Effects of culture media and stocking density on biofouling, shell shape, growth, and survival of the Pacific oyster (Crassostrea gigas) and the Manila clam (Venerupis philippinarum) in suspended culture. Aquaculture, 406-407(0): 68-78

Petraitis PS (1995) The role of growth in maintaining spatial dominance by mussels (Mytilus edulis). Ecology 76(4):1337-1346

Pouvreau S, Bourles Y, Lefebvre S, Gangnery A, Alunno-Bruscia M (2006) Application of a dynamic energy budget model to the Pacific oyster, Crassostrea gigas, reared under various environmental conditions. J Sea Res 56(2):156-167

Robertson GW, Cashin MJ, Merritt JH, Kolbe E (1987) Submersible structures for shellfish culture. Aquac Eng $6(2): 111-126$

Roegner GC, Mann R (1995) Early recruitment and growth of the American oyster Crassostrea virginica (Bivalvia: Ostreidae) with respect to tidal zonation and season. Marine ecology progress series. Oldendorf 117(1):91-101

Rosland R, Bacher C, Strand Ø, Aure J, Strohmeier T (2011) Modelling growth variability in longline mussel farms as a function of stocking density and farm design. J Sea Res 66(4):318-330

Sokal RR, Rohlf FJ (1981) Biometry: the principles and practice of statistics in biological research 2nd edition

Soletchnik P, Huvet A, Le Moine O, Razet D, Geairon P, Faury N, Goulletquer P, Boudry P (2002) A comparative field study of growth, survival and reproduction of Crassostrea gigas, C. angulata and their hybrids. Aquat Living Resour 15(4):243-250

Spencer B, Key D, Millican P, Thomas M (1978) The effect of intertidal exposure on the growth and survival of hatchery-reared Pacific oysters (Crassostrea gigas Thunberg) kept in trays during their first ongrowing season. Aquaculture 13(3):191-203

Syvret M, Fitzgerald A, Hoare P (2008) Development of a Pacific oyster aquaculture protocol for the UK: technical report. Sea fish industry authority, FIFG project no, 7 
Troost K (2009) Pacific oysters in Dutch estuaries. Causes of success and consequences for native bivalves., Department of Marine Biology, the Netherlands. Univeristy of Groningen, the Netherlands

Vincent B, Joly D, Harvey M (1994) Spatial variation in growth of the bivalve Macoma balthica (L.) on a tidal flat: effects of environmental factors and intraspecific competition. J Exp Mar Biol Ecol 181(2):223-238

Walles B (2015) In: Dissertation. Wageningen University (ed) The role of ecosystem engineers in the ecomorphological development of intertidal habitats, Wageningen

Zhang X, Zhu M, Li R, Wang Z, Xia B, Zhang L (2006) Density-dependent mortality of the scallop Chlamys farreri (Jones \& Preston) in grow-out culture. Aquac Res 37(8):842-844

Publisher's note Springer Nature remains neutral with regard to jurisdictional claims in published maps and institutional affiliations.

\section{Affiliations}

\section{Jacob J. Capelle ${ }^{1,2} \cdot$ Eva Hartog $^{1} \cdot$ Jorik Creemers $^{1}$ - Jouke Heringa ${ }^{1}$ • Pauline Kamermans ${ }^{2}$}

\section{Eva Hartog}

e.hartog@hz.nl

Jorik Creemers

Jorik.Creemers@Scheldestromen.nl

Jouke Heringa

jouke.heringa@hz.nl

Pauline Kamermans

pauline.kamermans@wur.nl

$1 \quad$ HZ University of Applied Sciences, Edisonweg 4, 4382 NW Vlissingen, the Netherlands

2 Wageningen University \& Research- Wageningen Marine Research, P.O. Box 77, 4400 AB Yerseke, the Netherlands 